\title{
RESEARCH NOTE \\ An analysis of the physical and germination parameters of the sweet Chestnut (Castanea sativa)
}

\author{
Susana Benedetti, Marta González, Edison García, and Iván Quiroz \\ Instituto Forestal. Sucre 2397, Santiago, Chile.
}

\begin{abstract}
S. Benedetti, M. González, E. García, and I. Quiroz. 2012. An analysis of the physical and germination parameters of the sweet Chestnut (Castanea sativa). Cien. Inv. Agr. 39(1): 185-192. This study analyzed the physical characteristics, number of seeds per kilogram, seed weight, germination characteristics, germination percentage, germination energy, germination period and the germination vigor of sweet chestnut seeds from two forest plantations in the Los Ríos region of Chile. No significant differences were found in any of the characteristics related to the collection zone. Following the international classification systems for seeds of this species, the values of the physical characteristics allow us to classify these seeds as a small caliber or "chestnut". The values of the germination characteristics $(>80 \%)$ demonstrate a good germination for chestnut seeds of forest origin.
\end{abstract}

Key words: Energy period, germination energy, germination percentage, germination vigor, number of seeds per kilogram, seed weight.

\section{Introduction}

Because it can be used as a fruit for both selfconsumption and animal feed, and because it can be commercialized in the domestic market, the sweet chestnut (Castanea sativa Mill.) has been traditionally grown in the South Central zone of Chile. In regard to the forest aptitude, the chestnut wood is part of an exclusive international market of highly-valued fine timber. In Europe, sweet chestnut forests are being revalued not only for their fruit and timber production, but for their role in the landscape and in increasing quality of life (Loewe and González, 2005). Other products derived from the sweet chestnut, such as honey

Received March 30, 2010. Accepted July 27, 2011 Corresponding author: susana.benedetti@infor.cl and high-value edible fungi, represent a significant periodical income in a strong international market. The large variety of products derived from the chestnut allowed it to obtain a position as a multipurpose species of high interest for small and medium scale owners; these owners were especially intrigued by the subsidy benefits for establishing forest plantations.

The chestnut is found between the regions of Maule and Los Ríos, and it has excellent adaptation and growth characteristics (Benedetti et al., 2007). In general, fruit orchards are located in the foothills of the Bio Bio region, while the forest plantations are located in the regions of La Araucanía and Los Ríos. The plantations in these two regions vary between 2 and 10 ha and 10 to 50 years old, and they are scarcely managed to optimize the exploitation of timber; the fruit is collected 
by local inhabitants and commercialized in the regional market for pastries or animal (especially pig) feed ("castaña chanchera").

In Chile, any fruit from the chestnut is called "castaña." However, in countries where the fruit from the chestnut is traditionally produced and consumed, the size or caliber (number of seeds per kilogram) of the chestnut determines whether or not the term "marrón" or "castaña" is used. Likewise, depending on their size, the chestnuts have different markets, and they are used for either fresh consumption or agro-industry (Grau, 1997). For forest plantations in Chile, the production system of chestnut plants is traditionally bare rooted. However, there is no information available regarding the behavior of seeds during the process of plant production. Knowing seed behavior during plant production is important for obtaining high quality plants for wood production, which is one of the fundamental phases in plantation generation and in silvicultural and management techniques. Seeds are a biological entity that interacts with environment components; therefore, their behavior cannot be absolutely anticipated. However, the concept of "seed quality" is fundamental for the sexual propagation of the species, and it is related to different aspects of propagation, such as conservation, material homogeneity, the probability of success in plant production and the application of advanced nursery techniques. The concept of "seed quality" also includes the genetic characterization of the seed and other important physiological aspects (Piotto and Di Noi, 2001). Nevertheless, the quality aspects that are most valued depend on the use of the seeds; in this case, their response in plant production is required.

Due to the high plantation costs, counting with quality vegetal material is necessary to ensure a successful investment. Therefore, having knowledge of seeds and their behavior becomes fundamental in order to quantify the amount of seed required for a specific surface, to ensure the efficiency of plant production and to guarantee a successful plantation establishment. This study was aimed at evaluating the physical and germination characteristics of sweet chestnut seeds from forest plantations located in the region of Los Ríos.

\section{Materials and methods}

\section{Germplasm origin}

The seeds used in this study were collected in April 2008 from two sweet chestnut plantations located in the region of Los Ríos; the first site was Las Minas, $39^{\circ} 55^{\prime} 16,89^{\prime \prime}$ South latitude; $73^{\circ} 13^{\prime} 54,9$ " South longitude, in the commune of Corral, and the second site was Pillo Pillo, $39^{\circ} 52^{\prime} 27,41^{\prime}$ 'South latitude; $73^{\circ} 06^{\prime}$ 59,48" South longitude, in the commune of Valdivia. The sweet chestnut plantation in Las Minas was established in 1978 at 58 mosl in the Northwest exposure and at a $14 \%$ gradient. The Pillo Pillo plantation was established in 1981 at 44 mosl in the South exposure and at an $18 \%$ gradient. The climate in both sites is classified as Marine; there is a Loncoche agroclimate in the case of Pillo Pillo, and a Castro agroclimate in the case of Las Minas. Las Minas has an average annual precipitation of $1942 \mathrm{~mm}$. It does not have a dry season and has five frost-free-months with a mean annual temperature of $10.49^{\circ} \mathrm{C}$. The mean maximum temperature is $19.4{ }^{\circ} \mathrm{C}$ and the mean minimum temperature is $3.2^{\circ} \mathrm{C}$. Pillo Pillo has an average annual precipitation of $2.139 \mathrm{~mm}$. It has three frost-free months and is dry in January and February. The temperature is higher than in Las Minas, with an annual mean of $12.5^{\circ} \mathrm{C}$. The mean maximum temperature is $27.1^{\circ} \mathrm{C}$ and the mean minimum temperature is $3.3^{\circ} \mathrm{C}$ (Novoa et al., 1989). In regard to the edaphic variables, both plantations share similar characteristics and are within the value intervals for some characteristics as indicated by the following literature for the species: the deep soils, between 80 and $100 \mathrm{~cm}$; the silt loam, with an apparent density between 0.59 and $0.69 \mathrm{~g} \cdot \mathrm{cm}^{-3}$; and the organic horizon, which is between 15 and $20 \mathrm{~cm}$ and 5 
cm-fallen leaves. Also, both plantations have a moderate $\mathrm{pH}$ between 5.04 and 5.01 (Benedetti and Saavedra, 2007).

On each plantation, the seeds were collected from the 30 trees that demonstrated the best form. The best form was determined by the highest shaft straightness, a lower number and diameter of branches and the sociological position (dominant trees). After collection, the seeds were stored in plastic containers and arranged in a cold chamber at a temperature between 4 and $5^{\circ} \mathrm{C}$, where they were kept for 39 days until sowing occurred on May 30. From the total seeds collected, a sample of 1,500 seeds was obtained from each plantation, and they were used for determining the physical and germination characteristics.

\section{Tests}

To achieve the described aim, tests were carried out at the Forest Plant Technological Center (FPTC), in the Bio Bio regional branch of the Forest Institute. The tests for the evaluation of the physical and germination characteristics were made in the seeds laboratory, and the tests for germination were made in a $200 \mathrm{mc}$-national nickel-plated UV polyethylene greenhouse at the same location.

The following physical characteristics were evaluated: the weight of 100 seeds, in a semianalytical precision balance (AND GF-400) to the hundredth of a gram, and the number of seeds per kilogram, which were counted manually, according to the methodology determined by the International Seed Testing Association (ISTA, 1996). This methodology consists of the weight determination of a 100 -seed sample that is repeated 8 times.

The following germination characteristics were evaluated: the germination capacity or germination percentage, germination energy, energy period and germination vigor.
For the germination tests, six $40 \mathrm{~cm}$-long, 63 $\mathrm{cm}$-wide and $14.5 \mathrm{~cm}$-high trays were used for each collection zone. The trays were composed by 24310 cc-volume cavities, and they had a $45 \mathrm{~mm}$-upper cavity diameter; each tray was included as a repetition. The harvest was made on May 30, 2008, and it consisted of placing one seed per cavity. The substrate used consisted of composted pine bark of G-10 grain size. The trays sowed in the greenhouse were arranged at random in two lines on a 1 meter-high board. They were, treated with weekly aspersions of a fungicide solution. The solution was composed of an equal proportion mixture of Benomilo and Ftalimida in a $0.5 \mathrm{~g} \mathrm{~L}^{-1}$ ratio, at a temperature of $22{ }^{\circ} \mathrm{C}$ and at a relative humidity of $80 \%$. The irrigation frequency consisted of a 10-minute-application applied twice daily from an automatic irrigation system. The germination results were recorded daily at 5 p.m. and for a period of 91 days. Pregermination treatments were not applied because the information and results from previous tests on sweet chestnuts in the same center indicated high germination percentages through direct harvest.

The germination capacity was obtained by counting the total number of seeds germinated in respect to the total sowing, which was then expressed by a percentage. The germination energy was determined according to the percentage of seeds germinated until the highest number of seeds per day was achieved. The number of days required to reach this maximum value is the energy period. The germination vigor was obtained by the Czabator value (1962), and it was expressed as the maximum value between the quotient of the daily mean germination and the number of days needed to reach that percentage. The formula is the following:

$$
\mathrm{GV}=\mathrm{DMG} / \mathrm{n}
$$

where $\mathrm{GV}$ is the germination vigor; $\mathrm{DMG}$ is the daily mean germination, calculated as the accumulated percentage of seeds germinated in any moment of the test; and $n$ is the number of 
days after the date of the harvest until that daily mean germination is reached.

\section{Design and statistical analysis}

The statistical software InfoStat version 2008/P was used to analyze the data statistically and to make a traditional analysis of variance (InfoStat Group, Faculty of Agrarian Sciences, National University of Córdoba. Córdoba, Argentina. 2008). Nevertheless, before that analysis, and to fulfill the normality assumptions of the statistical model used, it was necessary to transform the values of the measured variables that were expressed in percentages ( $\%$ of germination and germination energy). Therefore, the Bliss transformation (also known as an angular transformation) was used, which corresponds to the application of the following operation:

$Y^{\prime}=\operatorname{arcsen}(\sqrt{ }(p / 100))$

where $p$ is the value of the percentage of the variable observed (Ostle, 1968; Box and Hunter, 1989). The Tukey test was used for comparison (1953). The model was:

$$
\mathrm{Y}=\mathrm{U}+\mathrm{T}+\mathrm{R}+\mathrm{E}
$$

where $\mathrm{U}$ is the variable average, $\mathrm{T}$ is the effect of the treatment (zones of collection), R corresponds to the effect of the repetition (tray) and $\mathrm{E}$ is the residue or error not explained by the previous sources.

\section{Results and discussion}

\section{Physical characteristics}

The results obtained by analyzing the physical characteristics included in this study are presented in Table 1.

Significant differences were not observed among the zones of collection for the average weight in grams and the number of seeds per kilogram. The
Table 1. Average weight of 100 sweet chestnut (Castanea sativa) seeds and the number of seeds per kilogram.

\begin{tabular}{lcc}
\hline $\begin{array}{l}\text { Zone of } \\
\text { collection }\end{array}$ & $\begin{array}{c}\text { Average weight } 100 \\
\text { seeds }(\mathrm{g}) \pm \mathrm{SD}\end{array}$ & $\begin{array}{c}\mathrm{N}^{\circ} \text { of seeds } \\
\mathrm{kg}^{-1} \pm \mathrm{SD}\end{array}$ \\
\hline Las Minas & $867.3 \pm 44.3 \mathrm{a}$ & $115.3 \pm 5.9 \mathrm{a}$ \\
Pillo Pillo & $903.4 \pm 68.9 \mathrm{a}$ & $110.7 \pm 7.9 \mathrm{a}$ \\
Average & 885.3 & 113.0 \\
\hline
\end{tabular}

Different letters in the same column indicate a significant statistical difference, with $\mathrm{P} \leq 0.05$.

SD: Standard deviation.

results obtained for mean weight varied between 8.6 and $9.0 \mathrm{~g}$ per seed, with a mean weight of $8.8 \mathrm{~g}$. A range between 110 and 115 seeds was obtained for the number of seeds per kilogram, with a mean of 113 seeds kg-1 . Nevertheless, the zone of collection in Pillo Pillo demonstrated the highest values for the mean weight of 100 seeds and, consequently, the lower number of seeds per kilogram.

Donoso (1979) conducted a study on the variation and types of differentiation in the oak populations (Nothofagus obliqua (Mirb.) Oerst.) in Chile. This study proved that the variation in the weight and size of the seeds was a response of the adaptative divergence showed by vegetal species to the effect caused by habitat factors. Moreover, this study indicated a high correlation between a decrease in the weight of the seeds and the latitude from North to South, and that the size and dryness increases from South to North.

Although the plantations where the sweet chestnut seeds were collected for this study, Pillo Pillo and Las Minas, are close to each other and present similar environmental conditions, the Pillo Pillo plantation, located in a slightly more Northern position, has a higher average annual precipitation and two dry months. This is different from the Las Minas plantation, which has a lower average precipitation and lacks any dry months.

According to Heslop-Harrison (1968), and as cited by Donoso (1979), when the physiological significances have not been explained, then the existence of correlations between morphological characteristics and habitat factors might be 
interpreted as evidence of adaptive divergence. The values obtained for the mean weight in both plantations $(8.85 \mathrm{~g})$ are similar to the results obtained by Emrah and Fahrettin (2007) (8.86 g) for the heavier class seeds in a natural population of sweet chestnuts in Turkey, i.e., in a setting of a high density forest, similar to the plantations where the analyzed seeds were obtained.

In regard to the number of seeds per kilogram, the values obtained are found in the lower stretch of this range, although they are within the range indicated by Montaraz (2007) for sweet chestnut between 100 and 200 seeds $\mathrm{kg}^{-1}$, which are primarily in the area of Galicia, Spain. Likewise, the values obtained in this study are lower than the mean indicated by Berrocal et al. (1998), (150 seeds kg-1 , like for sweet chestnuts in Spain), and they are also lower than the values obtained by Gordon and Rowe (1982) in England, where the range varied between 150 and 300 seeds $\mathrm{kg}^{-1}$. Therefore, the sweet chestnut seeds obtained from the Chilean plantations in this study demonstrate a slightly larger size than the seeds from the comparable European plantations.

According to Saavedra (1981), the values obtained from an analysis of the number of seeds per kilogram in this study would classify these seeds as small caliber, i.e., more than 100 seeds $\mathrm{kg}^{-1}$. These numbers are similar to the calibers observed in Asturias (Pereira et al., 2005 ), where $80 \%$ of the determined cultivars presented calibers larger than 100 seeds $\mathrm{kg}^{-1}$. It is noteworthy that the sweet chestnuts in that Spanish region are primarily used for wood and fruit production.
The quality of the small caliber is verified when the obtained values are compared with the calibers observed by Grau (2003) in the evaluation of Italian, French and Japanese fruit cultivars introduced in Chile, which varied between 67 and 99 seeds $\mathrm{kg}^{-1}$. The quality if also verified when the obtained values are compared to the results of an analysis of seeds from the sweet chestnut orchards in El Carmen, the foothills of the Bio Bio region, where the average values obtained varied between 52 and 59 seeds $\mathrm{kg}^{-1}$ (Noria, 2000). The similarities and differences between the values obtained in this analysis and the cited studies occur primarily in the type of cultivation (either forest plantations or fruit orchards), the different aim of the productions (either timber in the first case or fruits in the second case) and the different management schemes, such as a high density, $3 \times 3 \mathrm{~m}$ in the forest case, with very tall individual trees and a small canopy or the low density schemes, which are $8 \times 8 \mathrm{~m}$ or 10 $\mathrm{x} 10 \mathrm{~m}$ in the case of fruits and involve individual trees with a short shaft and large canopy. Another

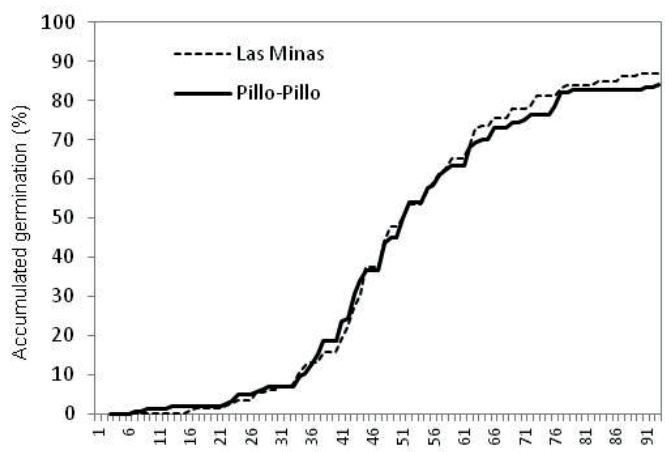

Figure 1. Accumulative germination curve of the sweet chestnut (Castanea sativa) seeds per collection zone.

Table 2. Germination percentage, germination energy, energy period and germination vigor of the sweet chestnut (Castanea sativa) seeds.

\begin{tabular}{lcccc}
\hline Zone of collection & $\begin{array}{c}\text { Germination percentage } \\
(\%) \text { SD }\end{array}$ & $\begin{array}{c}\text { Germination energy } \\
(\%) \pm \text { SD }\end{array}$ & $\begin{array}{c}\text { Energy period (days) } \\
\pm \text { SD }\end{array}$ & $\begin{array}{c}\text { Germination vigour } \\
\pm \text { SD }\end{array}$ \\
\hline Pillo - Pillo & $84.0 \pm 6.1 \mathrm{a}$ & $71.5 \pm 8.9 \mathrm{a}$ & $56 \pm 11.3 \mathrm{a}$ & $1.345 \pm 0.4 \mathrm{a}$ \\
Las Minas & $86.8 \pm 10.6 \mathrm{a}$ & $72.1 \pm 4.4 \mathrm{a}$ & $57 \pm 4.9 \mathrm{a}$ & $1.350 \pm 0.3 \mathrm{a}$ \\
Average & 85.4 & 71.9 & 56 & 1.348 \\
\hline
\end{tabular}

Different letters in the same column indicate a significant statistical difference, with $\mathrm{P} \leq 0.05$.

SD: Standard deviation. 
fundamental aspect influencing these differences and similarities is the type of vegetal material used for establishment, such as the wild sweet chestnut in the case of forest plantations, or the sweet chestnuts grafted with fruit selected cultivars in the case of the fruit orchards.

\section{Germination characteristics}

The results obtained from the germination analysis are presented in Table 2 and the corresponding germination curve is presented in Figure 1.

There were no significant differences attributable to the effect of the collection zones for the determined variables; nevertheless, a higher germination capacity or germination percentage was obtained with the seeds from the Las Minas area. The values obtained for germination, which were between 84.0 and $86.8 \%$, with a mean of $85.4 \%$, are slightly lower than the results obtained by Delard et al. (2007), who observed a $96.7 \%$ germination rate for the seeds from the forest plantations in Southern Chile. The results in this study are also lower than the results obtained by Emrah and Fahrettin (2007) for seeds from the natural populations of the sweet chestnut in Turkey, which had a variation between 91.3 and $98.8 \%$. However, the results from this study are higher than the values from plantations in England obtained by Gordon and Rowe (1982), which had a variation between 67 and 93\%.

In regard to the germination energy, no significant differences were observed because of the zone of collection. In regard to the energy period, both zones of collection showed a similar number of days (approximately 56 days). In the case of the germination vigor, just like the other evaluated variables, there were no significant differences attributable to the zones of collection.

It is worth noting that few studies, either domestic or international, have been conducted on the germination characteristics of the sweet chestnut seeds. This might be because the main reproduction methods used in the countries where the species is more highly produced, such as Italy, Spain and France, are basically vegetative cuttings (Berrocal et al., 1998).

However, many authors have indicated that the different seed sizes would reflect differences in their biological capacities (de Araujo Pedrón et al., 2004; Sánchez-Salas et al., 2006), especially between the characteristics of seed size and germination percentage. For some species, there is a directly proportional relationship, while for other species, the relationship is inversely proportional. Emrah and Fahrettin (2007) obtained significant differences when they related the size of sweet chestnut seeds with the germination percentage and germination value; in both cases, these values were higher with the larger seeds. The studies by Gordon and Rowe (1982), which demonstrate the lowest values for germination capacity, indicate a large amount of seeds per kilogram, i.e., smaller seeds. According to this finding, it might be deduced that there is a direct relationship between the seed size and germination capacity; however, this study did not analyze this aspect, which is considered a necessary evaluation to achieve a more efficient seed collection and plant production.

In conclusion, this study shows that there are no significant differences for the evaluated physical characteristics and germination attributable to both collection zones. The values obtained for the number of seeds per kilogram in both plantations are higher than 100 , with a mean of 113 seeds $\mathrm{kg}^{-1}$. According to these values and the other values analyzed in the discussion of this study, it is possible to validate the condition of the small caliber of sweet chestnut seeds from forest plantations. This is supported by the results obtained for the characteristic seed weights, which showed a range between 8.6 and $9.0 \mathrm{~g}$. When considering the evaluated germination characteristics, the results demonstrate that the sweet chestnut seeds from the forest plantations indicate an excellent response to germination; in this case, over $80 \%$ and with a mean of $85.4 \%$ through direct sowing. 


\title{
Resumen
}

\begin{abstract}
S. Benedetti, M. González, E. García e I. Quiroz. 2012. Análisis de características físicas y germinativas de semillas de castaño (Castanea sativa). Cien. Inv. Agr. 39(1): 185-192. Castaño es una especie que ha despertado interés en Chile como productora de madera y fruto, siendo considerada sujeto de bonificación forestal. Debido al alto costo de una plantación, es necesario disponer de material vegetal de calidad para asegurar el éxito de la inversión, por ello es fundamental conocer antecedentes de las semillas a fin de dimensionar la cantidad requerida para una determinada superficie y la eficiencia en el proceso de producción de plantas. En esta investigación se analizaron para semillas de castaño (Castanea sativa Mill.) provenientes de dos plantaciones forestales de la región de Los Ríos en Chile, las características físicas; Número de semillas por kilogramo y peso de semillas, y las características germinativas de acuerdo a la metodología establecida por la Asociación Internacional de Análisis de Semillas, ISTA (1996), capacidad germinativa, energía germinativa, periodo germinativo y vigor germinativo, a través de siembra y registros diarios de germinación durante un periodo de 91 días. Para el vigor germinativo se utilizó el valor máximo de Czabator. Los análisis se realizaron en el Centro Tecnológico de la Planta Forestal del Instituto Forestal. No se encontraron diferencias significativas atribuibles al efecto de las distintas zonas de colecta en ninguna de las características analizadas. Los valores obtenidos de las características físicas, permiten clasificar estas semillas como de calibre pequeño. Los valores obtenidos para las características germinativas muestran la excelente respuesta a la germinación de las semillas de castaño de origen forestal.
\end{abstract}

Palabras clave: Energía germinativa, número de semillas por kilogramo, periodo germinativo, peso de semillas, porcentaje de germinación, vigor germinativo.

\section{References}

Benedetti, S., J. Saavedra, A. Pavez, and M. Martin. 2007. Las plantaciones forestales. In: Benedetti et al. (eds.). Castaño madera de alto valor para Chile. INFOR. Santiago, Chile. p. 131-142.

Benedetti, S., and J. Saavedra. 2007. Caracterización ambiental y productiva de rodales forestales de castaño en Chile. Ciencia e Investigación Forestal 13:111-123.

Berrocal, M., J.F. Gallardo, and J.M. Cardeñoso. 1998. El castaño. Productor de fruto y madera. Creador de paisaje y protector. Madrid, España. Ediciones Mundi-Prensa. 288 pp.

Box, G., and W. Hunter. 1989. Estadística para investigadores. Introducción al diseño de experimentos, análisis de los datos y construcción de modelos. U.S.A. Edit. Reverté S.A. 675 pp.
Czabator, F.P. 1962. Germination value: an index combining speed and completeness of pine seed germination. Forest Science 8: 386-396.

de Araujo Pedrón, F., J. Pacheco, and N. Lemos de Meneses. 2004. Parámetros biométricos de frutos, endocarpio y semillas de butiazeiro. Ciencia Rural, Santa María 34:585-586.

Delard, C., M. González, O. Ortiz, M.P. Molina, and C. Lopez. 2007. Producción de plantas forestales. In: Benedetti et al. (eds.). Castaño madera de alto valor para Chile. INFOR. Santiago, Chile. p. $157-187$.

Donoso, C. 1979. Variación y tipos de diferenciación en poblaciones de Roble (Nothofagus obliqua (Mirb.) Oerst.). Bosque 3: 1-14.

Emrah, Ç., and T. Fahrettin. 2007.Seed size effects on germination, survival and seedling growth of Castanea sativa Mill. Journal of Biological Sciences 7: 438-441. 
Gordon, G., and F. Rowe. 1982. Seed manual for ornamentals and shrubs. London, Forestry Commission. Bulletin 059. 132 pp.

Grau, P. 1997. El Castaño. Un recurso pleno de potencialidades económicas. Tierra Adentro 12:1619.

Grau, P. 2003. Introducción de cultivares de castaño europeo (Castanea sativa Mill.), híbridos euro japoneses (Castanea crenata x Castanea sativa), y castaño japonés (Castanea crenata sieb et zucc.) a Chile. Primeros resultados. Agricultura Técnica 63:329-335.

ISTA . 1996. International rules for seed testing. International Seed Testing Association (ISTA). Seed Science and Technology. Vol. 24. Supplement Rules. 335 pp.

Loewe, V., and M. González. 2005. Castaño: especie multipropósito. Chile Forestal 309: 52-55.

Montaraz. 2007. Catálogo 2007-2009. Nacer, Crecer, Vivir. Semillas Montaraz. Available online at: http://www.montaraz.com/Docs/catalogo1.pdf (Website accessed September 16, 2008).

Noria, A. 2000. Algunas características físicas y morfológicas del fruto de castaño (Castanea sativa Mill.) de la comuna de El Carmen. Tesis Ingeniero Forestal. Universidad de Concepción. Concepción, Chile. 32 pp.

Novoa, R., S. Villaseca, P. del Canto, J.L. Rouanet, C. Sierra, and A. del Pozo, 1989. Mapa agro- climático de Chile. INIA. Santiago, Chile. 221 pp. y mapas.

Ostle, B. 1968. Estadística Aplicada. Técnicas de la estadística moderna, cuando y donde aplicarlas. México. Editorial Limusa - Wiley, S. A. 629 pp.

Pereira-Lorenzo, S., A.M. Ramos-Cabrera, M. Ciordia-Ara, and M.B. Díaz-Hernández. 2005. Características morfológicas e isoenzimáticas de los cultivares de castaño (Castanea sativa Mill.) de Asturias. Editorial Monografías INIA: Serie Agrícola. V. 16. España. 541 pp.

Piotto, B., and A. Di Noi. 2001. Propagazione per seme di alberi e arbusti della flora mediterranea. Manuale ANPA. Agenzia Nazionale per la Protezione dell'Ambiente Dipartimento Prevenzione e Risanamento Ambientali. Roma, Italia. $212 \mathrm{pp}$.

Saavedra, O. 1981. Perspectivas para el desarrollo de frutales tipo nuez en Chile. CORFO, Gerencia de Desarrollo AA 81/45. Santiago. Chile. 302 pp.

Sánchez-Salas, J., J. Flores, and E. Martinez-García. 2006. Efecto del tamaño de semilla en la germinación de Astrophytum myoriostigma Lemaire (Cactácea), especie amenazada de extinción. Interciencia 31:371-375.

Tukey, J.W. 1953. The problem of multiple comparisons. The problem of multiple comparisions. Department of Statistics, Princeton University. Chapman \& Hall, Nueva York. Nueva York, EEUU. 